D'Agostino, P.R. The blocked-random effect in recall and recognition. Journal of Verbal Learning and Verbal Behavior. 1969, 8, 815-820.

Mandler, G. Pearlstone, Z., \& Koopmans, M. H. Effects of organization and semantic similarity on recall and recognition. Journal of Verbal Learning and Verbal Behavior, 1969, 8, 410-423.

Wonderlic, E. F. How to use the Wonderlic Personnel Test. Northfield, IL: E. F. Wonderlic and Associates, 1978
Note

The author would like to thank J. Scott Mizes for his useful comments on earlier drafts of this manuscript.

Michael G. Aamodt

Department of Psychology

University of Arkansas

Fayetteville, AR 72701

\title{
METHODS AND TECHNIQUES IN TEACHING
}

\section{Use of Drama Students as "Clients" in Teaching Abnormal Psychology}

\section{Kirby Gilliland \\ University of Oklahoma}

One of the more difficult problems encountered in teaching abnormal psychology has been presenting course content in a manner which allows students to grasp the full meaning of the material in a factual sense and also be able to operationalize their knowledge in a "real world" setting. Bibace, Crider, Demick, and Freimuth (1979) noted that this problem is ". . related to the emphasis these courses placed on the memorization of what then seemed to be oddsounding labels for different types of people-people whom we never saw nor heard, but only read about." The important factor is that students need to observe and interact with people experiencing mental problems to better understand the full range and nature of specific clinical syndromes.

Several difficulties arise when one attempts to resolve this problem. Ethical considerations concerning the privacy of institutionalized patient populations may preclude the more meaningful aspects of class visits to mental hospitals. Logistical difficulties in managing exposure and supervision for as many as one hundred students (or more!) are selfapparent. Some rather unique attempts which were designed to circumvent these problems and offer practical clinical experience to abnormal psychology students have been reported. Simulated mental hospital wards were designed both as comprehensive experiences (Claiborn \& Lemberg. 1974), and as briefer simulation exercises (Schofield \& Klein, 1975) Commercial films (Nissim-Sabat, 1979) and audio/video tapes (Bibace, Crider, Demick, \& Freimuth, 1979) have also been utilized in presenting case study material. Although more general in their intent, structured game-like exercises (Gardner, 1976) and innovative, partially self-designed course formats (Ruble, 1975) have also been proposed. The purpose of this report is to present another innovative technique for presenting realistic clinical experience: The use of drama students trained to simulate psychopathological case studies during an in-class standard clinical interview.

The Simulation. An agreement was made with the university drama department to have as one of the class projects in a graduate acting course the presentation of six representative case studies each from one of the major diagnostic categories. Six graduate drama students were originally assigned to the project. Each student was given a case study - the selection based partially upon interest in a specific syn- drome, background and exposure to various syndromes. and obvious constitutional, demographic and gender similarity to the actual cases (although these can usually be modified to fit a wide range of potential actors). The case study material was extensive, much as one would find in an exhaustive intake interview. and supporting technical material on their specific diagnostic category and syndrome from several abnormal psychology and psychiatry texts. The drama students would then construct a character from the case study: supporting material, and their unique backgrounds. As these characters evolved, I would have a conference with the actor to refine his or her understanding of the technical information, the specific case study, and the most efficient and graphic way to present the case. Dress rehearsals of the presentation (clinical intake interview) were scheduled one week before the actual class presentation. These dress rehearsals were video-taped, and through discussion, analysis, and viewing of the video-tapes (as well as additional rehearsals, if needed) the presentations were refined to a surprising level of realism.

In some semesters the class in abnormal psychology was told that the presentations were by drama students. In other classes they were given a cover story to the effect that clients from a local community mental health clinic had volunteered to be interviewed concerning a mental problem from which they were recovering. Those classes who were deceived as to the nature of the "clients" they saw, were informed at the end of the first presentation that the "client" was really an actor. Thus subsequent presentations did not involve the deception. It was judged from a technical teaching standpoint and from the response of students that the approach involving an initial deception was the most effective. Students who were initially deceived reported that they were more impressed and were able to attend to subsequent presentations with more realism in mind than if they knew from the start that the clients were actors

The first in-class interview of a client/actor was done by the instructor or other trained mental health professional. This gave the students an opportunity to observe skilled interviewing practice and compare that to course content material on the subject. Subsequent interviews were often conducted by panels of three or four student volunteers from the class. The interviews were video-taped either by the instructor, instructional aides for the course, or by the university Instructional Service Center personnel. Following the interview, class discussion took the form of differentially diagnosing the disorder and suggesting possible treatment strategy. The importance of adequate information gathering technique (interviewing skill) and accurate diagnosis for the development of effective treatment plans were thus demonstrated. 
The potential for instruction was found to be high using this technique. Aside from the obvious real-life aspect of the demonstrations, the class as a whole was given the opportunity to ask questions after the formal interview was completed. The interviews and case study material can be designed to highlight particular problems or interesting features of the specific syndromes, various interviewing techniques, or problems interviewers often face. The quality of classroom discussion following the presentation can be improved immeasurabily by the ability of the drama students to slip in or out of their role for further questioning of the "client," if needed. A video or audio tape library can be developed for future use in teaching, supervision, or research. Finally, one unexpected result was that the drama students were highly enthusiastic and reported significant benefit from the challenge of learning a character from a psychological perspective and constructing a dialogue from a known character (case study), the opposite of what they usually are asked to do in their training.

Evaluation. This innovation was evaluated by comparing the course evaluations of two abnormal classes, one taught with the use of drama student clients (Spring semester) and one without (preceding Fall semester). The course content, text, and instructor were held constant. Four questions from standard course evaluations were compared. There were no significant differences between the classes based on initial interest in the subject material, $t(87)=0.21$, or the course workload, $t(86)=1,46$. However, the students in the course utilizing drama student clients did rate their course significantly higher in a rating of general course quality as compared to other university courses, $t(87)=2.63, p<05$, and they felt they learned significantly more in the course, $t$ $(87)=2.48 . p<.05$. as compared to the students in the course without drama student clients

On the basis of a survey concerning the quality and helpfulness of the drarna student-client presentations, $91 \%$ of the students surveyed felt the presentations were above average $(46 \%)$ or excellent $(45 \%)$ in quality (five point scale for all questions). Also, $94 \%$ of the students felt the presentations were helpful $(51 \%)$ or very helpful $(43 \%)$ in understanding the course material, and $88 \%$ felt moderately assured $(46 \%)$ or strongly assured $(42 \%)$ that the presentations aided in their mastery of applying the course material. Ninety-four percent of the students said they would definitely recommend $(26 \%)$ or strongly recommend $(68 \%)$ the class to other students
Discussion. The use of drama students as "clients" in the teaching of abnormal psychology has provided a unique learning experience for those taking the course as well as for the drama students who participated; has produced a valuable resource in the form of a video-tape library; and has provided a powerful technique for conveying more realistic clinical experiences. This innovation is not without cost. Considerable time must be spent by a clinically trained and experienced person to construct adequate case studies, amass pertinent supporting literature, and coach the drama students to produce believable and educationally useful case presentations. Video-tape capability is more demanding and not absolutely necessary, but it adds significantly to the ability to coach the drama students and supplies one of the major by-products, a video-tape library. Judging from the evaluation data and the enthusiastic response of those students exposed to the drama student client presentations, as well as the drama students themselves, it appears that this innovation adds significantly to the effective teaching of abnormal psychology

\section{References}

Bibace, F. Crider, C. Demick, J. \& Freimuth, M. The clinician's "World of Action" as an approach to teaching abnormal psychology. Teaching of Psychology, 1979, 6, 152-155.

Claiborn, W. L., \& Lemberg. R. W. A simulated mental hospital as a undergraduate teaching device. Teaching of Psychology, 1974 1. 38-40.

Gardner, J. M. The myth of mental illness game: Sick is just a four letter word. Teaching of Psychology, 1976, 3, 141-142.

Nissim-Sabat, D. The teaching of abnormal psychology through the cinema. Teaching of Psychology, 1979, 6, 121-123.

Ruble, R. Spicing up an abnormal psychology course Teaching of Psychology, 1975 2, 43-44.

Schofield, L. J., \& Klein. M. J. Simulation of the mental hospital experience. Teaching of Psychology, 1975, 2, 132-134.

\section{Notes}

1. The author would like to thank Diane Puglisi, Jean Ann Nicks, Chuch Highfill, Lisa Kaighn, Michael Foley, Joey Sanchez, and Bart E.bbink for their outstanding efforts as actor/clients; Alan Langdon, drama coach, for his cooperation in developing this innovation; and Dara Andress and Lisa Portwood for their efforts in videotaping

2. Address requests for reprints to Kirby Gilliland, Department of Psychology, 455 West Lindsey, DAHT 736, University of Oklahoma, Norman, OK 73019 